\title{
Od kampowej burleski do (post)konstruktywistycznego performansu. O sposobach noszenia sztucznej szczęki w poezji Mirona Białoszewskiego
}

\section{Anna Filipowicz}

Uniwersytecie Gdańskim

\begin{abstract}
Wspótczesny "zwrot materialistyczny" skłania do ponownego przemyślenia potencjału gender i queer studies poprzez konfrontowanie ich zakresu z refleksja nad tym, co rzeczywiste i namacalne. Dotyczy to zwłaszcza podejścia do problemu ciała zanurzonego w empirii choroby, a już zwtaszcza niepetnosprawnego, które wymaga przeszczepu lub noszenia protezy. Bywa ono bowiem ujmowane jako znak podmiotowości "w ruchu", zawsze gotowej na tożsamościowe "złożenie" oraz relacyjne stawanie-się-z-innym. Uzupetniane poprzez substytuty niepetnosprawne ciało przestaje $w$ ten sposób podlegać reżimom wiedzy/władzy, zyskując w zamian nowy polityczny potencjat, który daje się odczytać w porzadku subwersji i emancypacji. Szkoła sztucznych zębów (1978) Mirona Biatoszewskiego wydaje się synteza queerowych antycypacji poety oraz jego wyprzedzajacych epokę zainteresowań sfera ciała postludzkiego. Opisywane w utworze kłopoty użytkownika protezy obejmuja bowiem namyst nad zarówno zdyskursywizowana, jak i oporna wobec władzy dyskursu strona materialnej rzeczywistości. Noszenie sztucznej szczęki ujawnia więc w utworze kulisy "teatru ról społecznych", sposoby kreowania normatywnej tożsamości człowieka jako twórcy, partnera seksualnego, uczestnika życia codziennego. Staje się jednak także pretekstem dla bardziej fundamentalnych, ontologicznych rozpoznań - do kwestionowania granicy między podmiotem i przedmiotem, a zwłaszcza między biologicznym istnieniem oraz jego technologicznym przedłużeniem. Niepiękne, niesprawne i coraz bardziej nie-ludzkie ciało zdradza tu dzięki protezie swój kolejny po queerowaniu, performatywny aspekt, mocno zakorzeniony w fenomenie dysponujących sprawczościa realiów. U Białoszewskiego otwiera to podmiot na hybrydyczna egzystencję, będąca już zawsze skutkiem pozostawania-w-relacji oraz nieustannych negocjacji z dyktującymi warunki rzeczami. Poetycki namyst nad taka nieesencjalna tożsamościa zdecydowanie wykracza tym samym poza ramy poststrukturalistycznego paradygmatu. Obraz wspótkonstytuującego się z proteza człowieka można by już raczej umieścić w perspektywie poszukiwań wyprzedzających posthumanizm.
\end{abstract}

Słowa kluczowe: nowy materializm, „zwrot ku rzeczom”, sprawczość rzeczy, burleska, kamp, niepetnosprawność, proteza (zębowa)

Współczesne zainteresowanie materialną rzeczywistością coraz częściej łączy się ze zwątpieniem w absolutyzm języka, który jako jedyny miałby zakorzeniać człowieka w tym, co kulturowe. Towarzyszy temu zwykle postulat ponownego przemyślenia potencjału empirycznych realiów, zbyt długo lekceważonych przez zorientowany tekstualistycznie poststrukturalizm. W postkostruktywistycznym „zwrocie ku rzeczom" materia przestaje być zatem wyłącznie wytworem wiedzy/ władzy ${ }^{1}$, choć wyłania się zawsze na styku porządków kultury i natury, kultury i techniki (por. Bednarek 2012: 227240). Materia uwyraźnia się szczególnie podczas stawiania oporu ludzkiej woli lub w „przejmowa-

1 Najmocniej akcentują tę potrzebę postkonstruktywistyczne filozofie, które swe zainteresowanie realiami łączą z postulatem radykalnego odcięcia się od społeczno-kulturowych uwarunkowań poststrukturalistycznego dyskursu (m.in. przedstawiciele teorii aktora-sieci). Por. Gulik, Nowak 2013: 330-348. 
niu" jakiegoś działania od człowieka. Zwraca to uwagę na nieadekwatność tradycyjnych podziałów na przedmiot i podmiot, na bezcelowość przypisywania im z góry jakichś określonych kompetencji. W perspektywie przyjętych tu ontologii człowiek funkcjonuje zazwyczaj w dynamicznym systemie relacji z rzeczami, które nie pełnią już tylko roli zapośredniczającego kulturowe narracje pomocnika (por. Gulik, Nowak 2013: 340). W zamian przypominają one raczej nie-ludzkie obiekty, współdecydujące wraz zludźmi o dyskursywno-materialnym kształcie świata. Doskonale uzewnętrznia to choćby przykład uzupełnianego przez protezy/przeszczepy niepełnosprawnego ciała, które zdaje się przekraczać dotychczasowe ontologiczne porządki oraz konstytuować w hybrydalne istnienie: ludzko-nie-ludzkie, bio-technologiczne albo swojo-obce. Stanowi ono uobecnienie podmiotowości „w procesie”, dzięki sztucznym narządom stale otwartej na przedłużenie czy usprawnienie. A jednocześnie, dzięki tym samym narządom, nieustannie stabilizowanej, tak, aby móc funkcjonować jako normatywny fizyczny i społeczny byt (por. Domańska 2008: 14)².

Szkoła sztucznych zębów (1978) Mirona Białoszewskiego zdaje się pod wieloma względami antycypować postulowane przez „zwrot ku rzeczom” sposoby patrzenia na realia. Reprezentują je w utworze tytułowe sztuczne zęby, które przekształcają życiowe i twórcze zwyczaje swego użytkownika, skłaniając go do pytań o charakter relacji między człowiekiem a przedmiotem. Noszenie zębowej protezy pozwala bowiem odsłonić kulisy tworzonej przy jej pomocy normatywnej tożsamości, uzewnętrznić związany z wyglądem "teatr ról społecznych", rozważyć nowe sposoby ekspresji "ja”. "Szkoła” sztucznych zębów bywa również niekiedy „lekcją" bezradności, zwłaszcza, kiedy wpływ realiów na podmiotowe "bycie w świecie" niespodziewanie okazuje się kontrproduktywny. Doświadczanie własnego ciała, coraz mniej atrakcyjnego i sprawnego, a coraz bardziej zdanego na techniczne uzupełnienia, rozszerza jeszcze ten zakres poetyckich rozważań nad rzeczami - o namysł nad statusem i kompetencjami człowieka jako hybrydycznego bytu. To właśnie od jego dyskursywno-materialnego „złożenia” Białoszewski uzależnia w utworze trwanie tego, co podmiotowe, kulturowe, społeczne. Samo „złożenie”, podobnie zresztą jak powiązania z realiami, nie jest tu już jednak ani łatwo osiągalne, ani warunkowane tylko przez stronę ludzką.

\section{I}

Przywoływaną w Szkole... "historię pacjenta”, a przede wszystkim początkującego użytkownika sztucznej szczęki warto odczytać w kontekście trapiących poetę od lat stomatologicznych niedyspozycji. Opisywana w utworze potrzeba noszenia protezy okazuje się bowiem następstwem nawracających kłopotów Białoszewskiego z zębami, które z biegiem czasu okazują się coraz poważniejsze. Widać to już choćby w Półpasiec-noga-ząb. Sprawozdaniu z chorobowego tryptyku (2013: 146-154; pierwsze wydanie 1973), poetyckim "studium przypadku” raz tylko ćmiącego, raz wyraźnie pulsującego trzonowca, który doczekuje się w końcu "wyroku” ekstrakcji. Upragnioną ulgę w bólu wkrótce zakłóca jednak kolejna fala dokuczliwego pykania, zwiastująca rychły powrót problemu i utratę następnych zębów. To rozpisane na kilka utworów rejestrowanie dentystycznych dolegliwości można uznać za świadectwo stopniowego osuwania się w somatyczną prozaiczność (por. Rosiek 1993: 132), powolnego wkraczania w marginalny dotychczas porządek chorującego ciała. W ślad za tym idzie także przymusowa konfrontacja z własnym przemijaniem, które rzutuje na postrzeganie same-

2 O ciałoodczuciu osób żyjących z protezą szerzej pisze także Fellous 2003: 71-77. 
go siebie i świata. Odejmowane jeden po drugim zęby przyczyniają się zwłaszcza do zatraty poczucia tożsamościowej integralności, uchylenia obrazu "ja" jako zamkniętej całości, naruszania ciągłości istnienia. Cielesne ubytki zawieszają konstruujące podmiot sensotwórcze podziały i naruszają siatkę binarnych znaczeń, skutkując zachwianiem symbolicznego ideału osoby. Do fizycznego cierpienia, wywołanego najpierw stanem zapalnym, a następnie stomatologiczną interwencją, dołącza zatem poczucie wielopoziomowego zdekompletowania czy rozspojenia. Ratunek poeta zamierza znaleźć w zębowej protezie, której zadaniem ma być zredukowanie zarówno somatycznego, jak i symbolicznego wybrakowania. Obstalowana "na wymiar" sztuczna szczęka miałaby tutaj wypełnić anatomiczną wyrwę, a przez to również zrekonstruować rozmontowany tożsamościowy schemat. Poeta chce "dodać" do siebie "trzecie zęby" jak integralny element, który pozwoli przywrócić kontrolę nad wymykającą się rozumowi cielesną dziedziną i przezwyciężyć własną bezradność wobec jej niekontrolowanego „osobnienia".

Ale już pierwsze zetknięcie z protezą zdradza w utworze poważne trudności związane z noszeniem w ustach "obcego ciała". Wykonany u dentysty nowy zębowy "garnitur" od razu ewokuje bowiem szereg problemów, które dotyczą każdego, kto pozostaje niewprawny w jego używaniu. Przeznaczone do wkładania i zdejmowania mosty, zespolone z zębami metalowymi klamrami, wymagają od poety ciągłego angażowania uwagi, podejmowania lub zaniechania jakiegoś działania, radykalnej zmiany przyzwyczajeń. Podczas jedzenia protezę trzeba zatem chronić przed wypadaniem i na powrót mocować z pomocą języka, który dociśnie do podniebienia jej obluzowane części; przy próbie mówienia lepiej z kolei trzymać język z daleka, prowadząc go tak, by omijał wyrastającą przed nim blokadę "trzecich zębów". Podobne wysiłki nie zapobiegają już jednak ani wrażeniu brzmieniowego stłumienia, ani mechanicznego "trzeszczenia”, które generują umieszczone w ustach szczękowe zaczepy. W dalszej perspektywie poeta nie jest ponadto w stanie sprostać absorbującej ruchomości protezy, która, drażniąc i kalecząc dziąsła, znacząco ogranicza jego apetyt. Co więcej, przez swe właściwości sztuczne zęby utrudniają skupienie na najważniejszych dla Białoszewskiego czynnościach - zakłócają przebieg głośnego czytania (i do czytania ryzyko) czy proces marzeń sennych (W tych zębach sny/ z komplikacjami/ chce się coś wypluć/ nie można [...] jedyne wyjście/ przebudzenie). Skazuje wreszcie na ograniczenie intymnych kontaktów, które w obliczu technicznej zawodności protezy - wypadania, zacinania czy zaciskania - stają się dla inicjatora zbliżeń krępujące, zaś dla ich odbiorcy - nadmiernie ryzykowne (- to do czego one?/ do mitości, wiadomo, że też nie). Zamiast więc służyć przeznaczonym celom, sztuczne zęby zdają się jeszcze utrwalać i pomnażać wcześniejsze niedogodności, a nierzadko wręcz sprzyjać powstaniu nowych:

To siedzą, to lecą. Trzymać! się uczyć.

[...]

Mowa jak przez szybę. Trzeszczę.

Kotlecik torcik. Latają w gębie. Zęby też.

Obroty żucia. Którą obcość jeść,

którą usadzić? 
Nikt nie pozna. Bo jak? Ja też,

póki co nie domyślałem się

niczego ${ }^{3}$.

Zapewne dlatego z użytkowaniem protezy łączy się próba przezwyciężenia osobności "trzecich zębów" i zamiar ich spajającego "ja” oswajania. Zdaje się temu służyć umieszczanie związanych ze szczęką codziennych praktyk w dobrze sobie znanym porządku wyobraźni, w ramach konkretnych strategii metaforyzowania. Za marzeniem o podmiotowym scaleniu kryje się bowiem zwyczajowy w tej twórczości sposób opracowywania rzeczywistości - przez patrzenie na nią nie tylko okiem "słowiarza", ale również malarza i scenografa (por. Kopciński 1997: 380). Pozostaje to konsekwencją teatralnej wrażliwości poety, która z łatwością przekształca w spektakl zarówno utratę (części?) własnych zębów, jak i trudności z noszeniem ich niewygodnego zastępstwa. Proteza daje się zatem pomyśleć w kategoriach scenicznego rekwizytu albo elementu maski-twarzy, wokół której można by osnuć szereg "scenek z życia” - perypetii artykulacyjnych, konsumpcyjnych, erotycznych. "Teatr" tworzyłaby tu choćby gra języka ze sztuczną szczęką, dramaturgia jej podtrzymywania i omijania, mimiczna ekspresja warg, gestyka zakładania i zdejmowania zębów. Takie ujmowane poprzez pryzmat spektaklu noszenie protezy stawałoby się w utworze próbą zapominania o jej uciążliwej empirii, a przez to także szansą na zapośredniczone choćby przywłaszczenie zębowej konstrukcji. Ustawiana w perspektywie "przebieranki, maskarady, mistyfikacji” (Kanabrodzki 2004: 176) szczęka mogłaby bowiem wyzbyć się swej dosłowności i ulec metaforycznemu włączeniu (por. Fellous 2003), wymogom kulturowej reprezentacji, symbolicznemu przetworzeniu. Dla Białoszewskiego byłaby to strategia ucieczki od ukonkretnionego ciała, powrotu do humanistycznego dyskursu i ustanowionych przez niego znaczeń. „Partyturowa” poetyka wywodu czy wprowadzony w utworze podział "na role" okazywałyby się w ten sposób przymiarką do terapeutycznego obłaskawiania protetycznych realiów".

Włączeniu szczęki w dziedzinę myślenia teatrem zdają się sprzyjać najbardziej dobiegające „zza kulis" "głosy", które wyrażają dotyczące zębów komentarze (- przestanie boleć/ - przezwycięż/ - ty coś noś/ - czytaj w tym/ - gryź). Wśród nich wyróżnia się zwłaszcza opinia wstawiającego protezę dentysty, stanowiąca w utworze stały punkt odniesienia poety (- Od razu/ panu w tym lepiej). Białoszewski „inscenizuje” sposób noszenia "trzecich zębów” właśnie na modłę wypełniania lekarskich zaleceń, które po skończonym zabiegu przekazuje się pacjentowi. Uwagę zadowolonego z efektów swej pracy dentysty traktuje się teraz jak "prolog” inaugurujący związane z zębami komiczne "widowisko" i inicjujący sytuację ich pierwszego publicznego odbioru. "Ubierany" w protetyczną konstrukcję poeta może się więc tutaj rozpoznać jako główny uczestnik „teatralnej” interakcji w gabinecie dentysty staje się on bowiem pierwszoplanowym "aktorem”, który nakłada "maskę"protezę i "wystawia się" na pokaz na "scenie" dentystycznego fotela. To ustawienie w porządku bycia zobaczonym i nazwanym okazuje się w Szkole... założycielskie zarówno dla rzeczywistości "spektaklu", jak i dla marzenia o powrocie do tożsamościowego scalenia. Sprowadzona do osoby dentysty gabinetowa "widownia" powołuje pacjenta do zadań „aktora”, dając mu sposóbność do

${ }^{3}$ Wszystkie cytowane fragmenty utworu pochodzą z tomu Odczepić się i inne wiersze... Mirona Białoszewskiego (1994: 167169).

${ }^{4} \mathrm{O}$ obłaskawianiu życiowych wydarzeń przez zapis (w którym mieści się również teatralna partytura) pisze szerzej Sobolczyk 2002: 480 . 
rozpoczęcia zaimprowizowanego „przedstawienia”-maskarady. Mocą spojrzenia i słowa zapewnia ona poecie poczucie osobowego pochwycenia, wyodrębnienia ze stanu niezróżnicowania, osadzenia po stronie ciała, które może podlegać pozytywnej estetycznej waloryzacji. Komentarz medyka"koryfeusza" ustanawia w ten sposób włączający rytuał, w którym kondycyjna chwiejność podmiotu mogłaby ulec reprezentacji, a przez to także reintegracji; tak oczekiwanemu „wyobrażeniu i przeobrażeniu" (por. Rosiek 1997: 199). U Białoszewskiego w zaimprowizowanym na dentystycznym fotelu humorystycznym wkładaniu zębów aktualizowałby się zatem fantazmat o widzeniu samego siebie jako kompletnej osoby, niezdeprymowanej już żadnym cielesnym brakiem.

Odczytywana z perspektywy gabinetowego „przedstawienia” proteza zdaje się więc służyć łagodzeniu życiowej empirii oraz poetyckiemu „instalowaniu się w rzeczywistości" (zob. Kopciński 1997: 59). Funkcjonując w porządku plastycznej metafory i teatru protetyczna konstrukcja, przypomina tu po trosze druciany "kaganiec”, a po trosze klekoczącą odpustową zabawkę, pocieszny element wybrakowanego bieda-kostiumu. Przynależy ona w ten sposób do ulubionego rekwizytorium poety; do wytrąconych „z życiowej praktyki" (Sandauer 1973: 378) nieprzydatnych rupieci, które mogą stać się z łatwością "obiektami operacji wyobraźni” (ibidem). Te "ogrywane" w obrotach żucia "trzecie zęby" okazują się jednak w Szkole... czymś więcej niż kontrapunktem wcześniejszych obrotów rzeczy, są także źródłem brzmieniowych zabaw oraz parodystycznym zastępstwem zwyczajnego mówienia (trzeszczę) (zob. Kopciński 1997: 46). „Ja” mogłoby się tu zatem zrekonstruować kolejno w związanej z noszeniem protezy dracznej „przebierance” albo humorystycznej „prezentacji akcji, która rozgrywa się zwykle za kurtynami warg" (Kanabrodzki 2004: 209). Scalałoby się ono również w ukomicznianiu "dialogów" języka ze szczęką, w kołowrotkowym zacinaniu- „trzeszczeniu”, w nadawaniu mimicznej i gestycznej ekspresji karnawałowo-jarmarcznej dynamiki.

Taka wystawiana na pokaz teatralność szczęki wyraźnie przekracza jednak w utworze wyłącznie wymiar ludyczny i komunikuje zarazem poetycki sceptycyzm wobec samego procesu tworzenia symbolicznych projekcji. Noszenie protezy daje się więc także zinterpretować w porządku "krzywego zwierciadła" - jako manifest deziluzji (192) i demaskacja mechanizmów tradycyjnego ujmowania człowieka. Przez eksponowanie nie-autentycznego charakteru "trzecich zębów" Białoszewski wyraźnie wskazuje bowiem na rozziew między scalającym „ja” wyrokowaniem "widowni” a pozorem uzyskiwanego dzięki szczęce zespolenia. Unaoczniona w Szkole... sztuczność zębowej konstrukcji podważa natomiast możliwość faktycznego tożsamościowego skompletowania, które miałoby się spełniać podczas "rytuału” w gabinecie dentystycznym. Nie sprzyja temu szczególnie równoczesne uruchamianie literalnych znaczeń protezy; wprowadzenie porządku atrapy zębów, która stanowi zarazem substytut i kopię cielesnych rejestrów. Zapewne dlatego traktowane jak teatralny rekwizyt "trzecie zęby" mogą wyłącznie o d g r y w a ć rolę tych własnych, anonsując przy tym stale swój falsyfikatowy charakter, istotową nieprzystawalność, odległe od naturalnego funkcjonowanie (mowa jak przez szybę, trzeszczę). U Białoszewskiego taka zacinająca się, trzeszcząca i tłumiąca dźwięki szczęka obwieszcza zatem dobitnie swój "wytworzony” i „zmontowany" charakter, wywołując zarówno efekt komizmu, jak i wrażenie przygodności czy prowizorki. Nie pozostaje to bez wpływu na status stanowionej z jej udziałem osoby, nie tyle scalonej, ile właśnie złożonej, skonstruowanej, „zmajstrowanej”. Z żartobliwej maskarady wyłania się dzięki temu ironiczno-gorzkie "maskowanie”, które dotyczy nie dającego się już ani ujednolicić, ani jednoznacznie skodyfikować podmiotu. Pro- 
teza staje się narzędziem demistyfikującego rozpoznania - zamiast gwarantować spójność "ja”, anonsuje ona wyłącznie jej pozór.

Zdaniem wielu krytyków u Białoszewskiego daje się bez trudu wyczytać zarówno świadomość iluzorycznego doświadczenia "ja”, jak i wyczucie kulturowych mechanizmów konstytuowania osoby $^{5}$. To poetyckie zwątpienie w zachowanie tradycyjnych prerogatyw podmiotu nie wpływa jednak w Szkole... na zmianę strategii dotyczących teatralnego obmyślania protezy, jej inscenizacyjnego opracowania czy projektowania zorientowanego na "widownię" odbioru. Przeciwnie, wobec wrażenia osobowego rozspojenia intensyfikuje się tu jeszcze potrzeba "reżyserowania” związanych ze szczęką sytuacji. Białoszewski wyraźnie udramatycznia sposoby codziennego użycia sztucznych zębów i operuje uzyskanym dzięki nim efektem cielesnego skompletowania. Posiłkuje się przy tym porządkiem parodii, za pośrednictwem której w "sceniczne" "dzianie się" można włączyć także poczynione dzięki protezie dekonstrukcyjne już z ducha rozpoznania. „Demiurgiczne” dążenia podmiotu zderzają się bowiem w utworze $z$ wyraźnym zwątpieniem w tożsamościową esencjalność człowieka, zaś stylizowany na jarmarczny teatrzyk łączy z przewrotną tragifarsą, której przedmiotem okazuje się być niemożność ostatecznego scalenia się osoby. W ślad za komizmem idzie więc tutaj sceptyczny dystans oraz gorzkie ironizowanie na temat własnych wyobraźniowych przyzwyczajeń. W ramy wywodu przedstawionego powyżej Białoszewski wpisuje w ten sposób jeszcze jeden, tym razem bardziej prześmiewczy "spektakl”, w którym noszenie sztucznej szczęki zyskuje zarazem autodemaskacyjny, jak i konstruujący nowe znaczenia charakter. Uwidacznia się w nim szczególnie kulturowe sposoby "wytwarzania” człowieka, który z pomocą protezy-rekwizytu stara się odegrać własną "naturalność" oraz odzyskać iluzję władzy nad samym sobą.

Próba pozorowania tożsamościowego scalenia wiąże się w utworze z autoreferencjalnym nagromadzeniem parodystycznych strategii, z delegitymizacją i ponownym wytyczaniem zakresu własnej metafory (por. Kopciński 1997: 41). Przebiega ona na drodze uzewnętrzniania mechanizmów konstytuowania podmiotu i prezentacji kulturowo-społecznych reguł, które decydują o wrażeniu osobowej kompletności. Odczytywany w porządku deziluzyjnego "spektaklu” komentarz dentysty staje się więc teraz także aktem ustanawiania procesu identyfikacji użytkownika sztucznych zębów. Dzięki przytoczeniu mu wzorca "dobrego" wyglądu czy wezwaniu do dalszej realizacji normy lekarz powołuje bowiem pacjenta do pełnego społecznego zaistnienia. Całkowicie udane odegranie ideału warunkowałaby jednak dopiero deklarowana przez posiadacza protezy znajomość obowiązujących w tym względzie standardów, jego publiczne "zdawanie sobie sprawy” z wytycznych paradygmatu. U Białoszewskiego widać to choćby w manifestacyjnym noszeniu protezy, którego efektem zdaje się być właśnie pozyskanie wrażenia stabilnej "całości” i „pełnoprawnego" statusu osoby (- to do czego one?/ [...] - do widoku dla was / - tylko? / - tylko, na samotnej wyspie / bym se darowat; na wystawie / [czyjejś] [podkreśl. moje - A.F.]). Komunikowanie świadomości normy ujawnia się także w zamiarze posłusznego podporządkowania się poleceniom otoczenia, mającym w wywodzie charakter performatywnych aktów. Jako chór głosów reprezentują one działanie dyscyplinującej foucaultowskiej władzy, której zadaniem jest ujarzmianie rozkiełznanego podmiotu i ponowne wikłanie go w społecznie aprobowane dyskursy.

5 Por. m. in. Niżyńska 2008: 272-291; Sobolczyk 2007: 326-328; Kanabrodzki 2004: 180-181. 
$[\ldots]$

- przezwycięż

- przywykniesz

- ty coś noś

- czytaj w tym

- gryź

Od zainicjowanego u dentysty wkładania "trzecich zębów” zależy więc w Szkole... sposobność odgrywania ideału "ja" i imitowania siebie kompletnego. Decyduje o tym zwłaszcza performatywny charakter lekarskiego nazywania, który Białoszewski ujmuje w znanym z pism Judith Butler (2010) znaczeniu interpelacji - wypowiedzi, która wyodrębnia, definiuje i warunkuje substancjalność nazywanego. Językowemu ustanawianiu podmiotu trwałość nadaje tu jednak dopiero społeczny rezonans - słyszane na co dzień komentarze, opinie czy rady otoczenia, rozpisane na szereg różnorodnych illokucyjnych aktów i podtrzymujące pozyskane u dentysty wrażenie tożsamościowego scalenia. To dzięki nim użytkownik protezy może bowiem nieprzerwanie materializować osobową normę oraz reprodukować ją raz po raz "na powierzchni” własnego ciała. Stąd właśnie wynika widoczne w utworze inicjowanie towarzyskich spotkań, które mogłyby sprzyjać kolekcjonowaniu takich mających sprawczy potencjał ostrzeżeń, napomnień, poleceń albo prowokowanie sytuacji, podczas których padałaby słowa podtrzymujące obraz skodyfikowanego podmiotu. Ich mnogość poeta organizuje zresztą w porządku kolejnego "widowiska”, jeszcze jednego "spektaklu”, który stanowi dopełnienie poprzednich. Do zaimprowizowanej dla siebie zabawy-„przebieranki”, a następnie kameralnego „pozorowania" cielesnego zespolenia Białoszewski dokłada teraz obliczone na szerszy odbiór "występy” w sztucznej szczęce, w której prezentuje się gronu bliższych i dalszych znajomych. Przez rozmyślną grę ze społeczną widownią teatralność noszenia protezy ulega zatem w Szkole... przekształceniu, zagęszczeniu, zdecydowanemu formalistycznemu zorientowaniu. Ciąży stopniowo w stronę coraz bardziej świadomej swej imitacyjnej natury i nieustannie to anonsującej maskarady.

Prezentowanie sztucznej szczęki przed szerokim odbiorcą odbywa się w utworze w parodystycznie potraktowanej konwencji średniowiecznego intermedium. Noszący "trzecie zęby" poeta przydaje bowiem swoim "występom” zadanie żartobliwego "międzyaktu”, który rozdziela od siebie inne społeczno-kulturowe widowiska lub pojawia się w trakcie ich przerw. W ramach swoistego "antraktu w antrakcie" publiczności zapewnia się tutaj niezobowiązującą na pozór rozrywkę - opowiadanie związanych z protezą przygód, perypetii, anegdot, połączonych nierzadko z elementami pantomimy. Białoszewski "rozgrywa” je przy każdej okazji - w przedpokoju, korytarzu czy poczekalni, ale również w teatralnych czy muzealnych kuluarach:

Na wystawie

(czyjejś).

Artur S. do mnie

- zębów nie masz?

- mam

- pokaż

$-\mathrm{O}$

- nie widzę, pokaż tak - szczerzy 
wyszczerzyłem

- aha

Lu. podchodzi

- to skąd pan? wtajemniczony?

- wtajemniczony

Sama publiczność pełni z kolei rolę osobliwego, niby-antycznego chóru, który czynnie współuczestniczy w autoidentyfikacyjnym "spektaklu" poety, wydatnie przyczyniając się do konstruowania wrażenia scalenia. Za pośrednictwem zasłyszanych od niej napomnień, zaleceń, rad czy sugestii może się teraz dokonać zarówno ustanawianie osoby, jak i zachęta do nieprzerwanej kontynuacji własnego społecznego konstytuowania. Poprzez podchwytywanie cudzych spojrzeń czy aranżowanie publicznych "konsultacji” poeta zdaje się więc cieleśnie "zespalać”, a następnie odgrywać przed swymi widzami tak pożądany przez siebie podmiotowy ideał. Ten uwyraźniony w Szkole... społeczny oddźwięk przywołuje modelową w performansach sytuację odbioru, w którym widownia sekunduje performerowi przy tożsamościowym improwizowaniu czy wyborze "właściwych" kodów znaczeniowych (por. Czapliński 2012: 21).

Obecne w utworze inscenizowanie wrażenia całości oraz zwielokrotnianie różnych typów dystansu wobec empirycznej i kulturowej rzeczywistości zdaje się uzasadniać zwłaszcza tęsknota poety za nieosiągalnym już powrotem w dawną domenę podmiotu. W komunikującym swą teatralność autotematycznym i autoreferancjalnym - tożsamościowym "spektaklu” mieści się bowiem stały namysł nad niewyczerpanym wciąż potencjałem nieubłaganie dekonstruujących się znaczeń. Białoszewski nie rezygnuje więc wcale ze swych lokowanych w modernistycznych wzorcach kultury upodobań, choć coraz częściej może do nich sięgnąć jedynie za pośrednictwem demaskacyjnych strategii. Uwidacznia to w utworze poetyckie operowanie parodią, za którym kryje się ciągła potrzeba twórczego dialogu z uobecnianym poprzez deformację humanistycznym modelem tworzenia 6 . Parodię traktuje się także jak sposób rozładowania lęków; formę ucieczki przed coraz bardziej dojmującą rzeczywistością (zob. Sobolczyk 2007: 333) - w dwuznaczność, w reprezentację, w grę konwencjami. Zapewne dlatego za budowaniem dystansu stoi w Szkole... marzenie o dawnej swobodzie tworzenia, mówienia czy śnienia, a nawet o przywróceniu zatraconego wraz zębami „zwyczajnego" wyglądu. Na nim zresztą zależy Białoszewskiemu szczególnie - skompletowanie uzębienia staje się dla niemłodego już poety szansą na zachowanie ubywającej seksualnej atrakcyjności. To również dlatego parodiowanie sposobów wytwarzania normatywnego podmiotu współwystępuje w utworze z przekornym zaangażowaniem w jego konstruowanie, które ma na celu „odzyskiwanie" siebie - własnych nawyków, zwyczajów, relacji - jeszcze sprzed początku dentystycznych problemów. Pomocne okazuje się w tym zwłaszcza estetyzujące spojrzenie społecznej widowni, w którym, niczym w lustrze, można nie tylko odegrać tożsamościowy ideał, ale także ustawić go w porządku uwodzenia:

${ }^{6}$ Jak zauważa Jacek Kopciński (1997: 41) takie formy ironicznego i parodystycznego dystansu często mają u poety charakter tzw. parodii konstruktywnej. 
- chciałeś się odchudzić. Zamiast palić, masz zęby. Wydłużają, wyszczuplają.

- to twarz

- wszystko się łączy

Przeciwstawianie się zatracie seksualnego powabu dokonuje się w utworze za pośrednictwem „przystrojonej” w "trzecie zęby" twarzy, którą poeta lokuje w porządku już ostatniej, pomyślanej tym razem w mikroskali, "sceny”. U Białoszewskiego toczą się na niej naraz aż dwa mimiczne "spektakle", oba w pełni zależne od sposobu noszenia w ustach sztucznej szczęki. W pierwszym poeta „inscenizuje" na twarzy szereg normatywizujących cielesność min i grymasów, które już dzięki samej obecności protezy zdają się tworzyć udany pozór osobowej całości. W drugim - materializuje tutaj konwencjonalny wzorzec homoseksualnej atrakcyjności, oczekiwaną młodość i szczupłość, uzyskiwanych poprzez fizyczne parametry zębowej konstrukcji. Sztywność protezy nadaje bowiem poetyckiemu obliczu dyscyplinujące ramy - nie tylko stoi na straży nienagannych proporcji czy młodzieńczego owalu twarzy, ale odpowiada także za jej dystyngowaną pociągłość, wzmacnianą jeszcze przez kłopoty z jedzeniem. Twarz "odgrywa” więc w Szkole... prześmiewczą historię zarazem zniewolonego, jak i uwodzącego ciała, podczas gdy sama proteza pełni w niej aż potrójną funkcję: "knebla”, "stabilizatora” i erotycznego „wabika”. Stanowi ona w ten sposób zdekonstruowany rekwizyt opresji, który poprzez poetyckie przeplatanie mechanizmów iluzji i deziluzji zyskuje odpowiednio groteskowy, ironiczny, a wreszcie zbliżający się do subwersywności wymiar. U Białoszewskiego takie "strojenie się" w zęby sprawia, że ciało staje się miejscem przecięcia wielu perspektyw, wykraczając poza narzucone mu odgórnie, stałe kulturowe kategoryzacje. Proteza ustawia cielesny ideał w porządku absurdalnego żartu; jako uwidoczniony tożsamościowy "wspornik" jest ona kpiną z oczywistych na pozór definicji osoby, płci czy pożądania. Zapewne dlatego przypomina tu najbardziej rekwizyt wyjęty z kampowej burleski, który narusza „naturalność” seksualnej ekspresji na rzecz jej farsowego odegrania.

„Wystawione” na pokaz sztuczne zęby zdają się przez to znakiem współwystępowania przeciwieństw, zawieszającym możliwość przyjęcia jednoznacznych tożsamościowych podziałów i heteronormatywnych klasyfikacji. Białoszewski obnaża umowność biegnących miedzy nimi granic z pomocą strategii zwielokrotnionego dystansu, szczególnie zaś poetyk karykatury i farsy. Swym efektom komicznym poeta przydaje jednak z miejsca przewrotny, ambiwalentny wymiar, wyposażając je w podwójny, skierowany zarazem "na zewnątrz" i "do wewnątrz" demaskatorski potencjał. Za obnażaniem sztuczności tożsamościowych kodów podąża tu bowiem stałe unaocznianie tęsknoty za tworzoną przez nie dotąd iluzją; za "kompletnością" czy "naturalnością" samostanowiącego się podmiotu. Prześmiewczy dystans paradoksalnie służy tu więc także podtrzymywaniu podważanego przez siebie porządku, nie dopuszczając w rezultacie do jego całkowitego zakwestionowania. Blisko stąd zwłaszcza do logiki mniejszościowego kampu, o której pisze Przemysław Czapliński (2012: 29), że odsłania i dowartościowuje dwuznaczności poprzez grę utożsamienia i oddalenia. Po poetyckim „kroku w przód”, czyli ujawnieniu nie-naturalności podmiotu, Białoszewski podejmuje w ten sposób "krok w tył, czyli afektowany [...] sygnał akceptacji status quo" (ibidem). Tej „karnawałowej inwersji" (ibidem) nie towarzyszy w rezultacie akt pełnej subwersji ${ }^{7}$, ani krytyczne unieważnianie fundujących

7 Zdaniem J. Niżyńskiej (2008: 289), dzięki poruszaniu się poety między rejestrami afirmacji i oporu, negocjacji między asymilacją a stawaniem się innym, subwersywność ulega w jego twórczości naturalizacji. 
humanitas ram. Przez teatralność noszenia protezy poeta dąży już raczej do odzyskania nad nią fizycznej i symbolicznej kontroli. Do sytuacji, w której myślenie o protezie byłoby na powrót prowadzoną wyłącznie na jego warunkach grą (31).

\section{II}

Założonych w gabinecie sztucznych zębów nie daje się jednak w ten sposób przywłaszczyć, włączyć w reguły coraz bardziej wyrafinowanych poetyckich "teatrów”. Z przypisaniem "trzecich zębów" do kategorii scenicznego „rekwizytu” kłóci się zwłaszcza ich nieustabilizowany status, który wymyka się z zasady klasyfikującej podmiotowej kontroli. W utworze wyraża się to nie tylko w planie „technicznych" kłopotów z noszeniem ruchomego "obcego ciała”, ale wiąże także z niemożliwością jego tradycyjnego obmyślenia. Zęby, które to siedzą, to lecq uobecniają bowiem - same w sobie - niepodleganie mechanizmom strukturalizowania rzeczywistości, podważanie porządku sensotwórczych podziałów, brak subordynacji względem znaczeń przypisanych biologicznemu ciału. Ani pod wpływem performatywnych konstatacji dentysty, ani na skutek wysiłków poety proteza nie ulega więc wcale poznawczej identyfikacji; jednoznacznemu symbolicznemu przyswojeniu. Przywodzi już prędzej na myśl konceptualną przeszkodę, która daje odpór ponawianym raz po raz próbom jej jarmarcznego, farsowego czy nawet kampowego przezwyciężenia. U Białoszewskiego szczęka zdradza w ten sposób podwójne nie-wpasowanie - nie mieści się zarazem w porządku anatomii oraz w planie dyskursu, przedstawiania, opisywania.

Usytuowana między zobaczonym i ukrytym, między porządkiem publicznym a prywatnym proteza przekracza również ramy kolejnych binarnych hierarchii. Na kwestionowanie przez szczękę porządku somatycznych granic wskazuje choćby brak jej przynależności do dziedzin cielesnego wnętrza lub zewnętrza. Umocowana na dziąsłach konstrukcja nie pozostaje tu bowiem jedynie źle działającym remedium na groźbę tożsamościowego rozspojenia. Dotyczą jej także znaczenia ust jako abiektalnego przedsionka, który konotuje niepokojące preedypalne niezróżnicowanie oraz godzi w podstawy upodmiotowienia. Protezę można więc przypisać do sfery "międzybycia", rozciągniętej między "ja" a "nie-ja” i reprezentującej istnienie "kompozytowe, coś, co podmiot Pragnie odrzucić, aby osiągnąć niezależną tożsamość" (por. Olsen 2013: 163). Aberracyjna ruchomość szczęki kojarzy się dzięki temu ze zwielokrotnionym kwestionowaniem kulturowego ładu (Kristeva 2007: 10), z nieprzerwaną i niekontrolowaną transgresją, z różnicowaniem bez ostatecznego wyodrębnienia. Skutkuje to w Szkole... obcowaniem z wyzbytą koordynacji materią, która wciąż zdradza tendencję do niespodziewanego dla swego użytkownika obluzowywania lub wypadania (To siedzą, to leca). Taką niekoherencję zwielokrotnia jeszcze uwidocznione przez Białoszewskiego przeżuwanie, w trakcie którego zaciera się podział na rodzaj konsumowanych treści, ich strukturę, pochodzenie, a nawet przeznaczenie:

Kotlecik torcik. Latają w gębie. Zęby też.

Obroty żucia. Którą obcość jeść,

którą usadzić? 
Przy deserze, kawałki jedzenia z obiadu, które dostały się pod protezę, utkwiły na zaczepach i w szczelinach zębów, w „zadrutowanych" protezą ustach, są wypychane przez kęsy tortu. Obracane wraz z nim językiem tworzą gładką tortową masę, by w drodze do przełyku niespodziewanie napotkać na twardość sztucznych zębów. To, co ma być przełknięte tworzy bowiem bezforemną, kleistą papkę, której ciągliwa konsystencja współistnieje z plastikowo/ceramiczno-metalową twardą konstrukcją niejadalnej, choć mimowolnie jedzonej protezy. W Szkole... łączą się więc ze sobą oscylujące na przeciwstawnych biegunach wrażenia: smakowe (słony/słodki), dotykowe (miękki/ twardy, gładki/ostry), a nawet dźwiękowe (mlaskanie/trzeszczenie); odmienne stany skupienia (półpłynny/ stały), rozmaite formy oraz postaci materii (bezkształtna masa kotleta i tortu, sztywna proteza). W zestawieniu z tym, co organiczne (ślina, dziąsła) czy wytworzone (torcik, kotlecik "trzecie zęby"), spożywany w protezie obiad przywodzi na myśl niepokojący substancjalny konglomerat, który jednocześnie intryguje i odstręcza, ewokując obrzydzenie oraz odrzucenie. U Białoszewskiego stanowi on zamach na tradycyjny humanistyczny paradygmat oraz przypisane do niego zmysłowe poznanie, na świat kulturowych norm czy reguł. Podczas celebrowania imieninowego posiłku proteza paradoksalnie „wyrzuca” swego użytkownika poza nawias społecznego systemu. W okolicznościach tworzenia biesiadnej wspólnoty przyczynia się ona do separacji poety od reszty konsumujących i rozerwania łączących go z nimi więzi.

Zagęszczona sensualność kotlecika czy torcika przywołuje w utworze znaczenia libidalnej materialności, seksualnych popędów wydobywanych na powierzchnię z głębin nieświadomości. Uzupełnia ją jeszcze akt groteskowego "autokanibalizmu", który wyraża się w jedzeniu nieprzywłaszczonych całkowicie "trzecich zębów" - nie dość swojskich, by móc przezwyciężyć wrażenie preedypalnej dezintegracji, a jednak dość własnych, by ich przeżuwanie konotowało wyraźne suicydalne inklinacje. Różnorako motywowana nieokreśloność protezy, złączona z jej osadzeniem w abiektalnym porządku, uniemożliwia zatem już na wstępie tak oczekiwaną przez poetę pełną reintegrację osoby. Rozumiana w ten sposób proteza, przynależna do wyzbytej ram, "wylewnej” przestrzeni, wymyka się bowiem władzy świadomości, kontroli strukturalizującego rozumu, wszelkim tradycyjnym dyskursywnym ustawieniom. Na jej fizyczne granice nakłada się w zamian kategorialny bezład, który z jednej strony wyraża powrót Realnego, z drugiej zaś związaną z tym ściśle niemożność ustanowienia osoby, która "nigdy nie wyłania się z mieszanek" (Olsen 2013: 62). Proteza pomyślana z początku jako "forma dla ciała” zdaje się w rezultacie do reszty rozmontowywać niespójną już wcześniej figurę "ja", spychając nadwątlony podmiot w nieświadomość, ku nieokreślonym siłom, energiom, popędom. Stąd właśnie bierze się wiodąca przez las nauka noszenia szczęki, która staje się przede wszystkim lekcją zwielokrotnionej poetyckiej bezradności. Jest to bezradność wobec polimorficznego chaosu libido, dalekiego od obrazu normatywnego siebie-ciała:
[...] Ja też,
Póki co, nie domyślałem się
Niczego. Tyle że nauka prędsza
Przez inny las. Co był w nas.

Ten dezintegrujący potencjał protezy manifestuje się jednak najmocniej na poziomie jej funkcjonalności, w powszednim użyciu. Widać go zwłaszcza w konotowanym przez "trzecie zęby" zawieszeniu podziału na aktywny podmiot oraz pasywny przedmiot, które uniemożliwia poecie noszenie 
protezy również w dosłownym znaczeniu. Trudności w jedzeniu, mówieniu, czytaniu nie tylko bowiem potęgują wrażenie wszechobecnego wybrakowania człowieka, ale fizycznie krzyżują mu szyki na wszystkich poziomach codziennych aktywności. Sztuczna szczęka pozostaje oporna zarówno wobec ujarzmiającej władzy świadomości czy rozumu, jak również wobec pełnienia zadań przydatnego narzędzia, o którego właściwościach decydowałaby właśnie myślący podmiot (61). Zamiast więc dać się posłusznie kształtować, sprzyjać tworzeniu granic czy uobecnianiu kategorii społecznych (63), ostatecznie reprezentuje ona całkowitą epistemologiczną obcość, która traci status biernego pośrednika w relacjach miedzy "ja” a światem. „Trzecie zęby” przestają u Białoszewskiego stanowić zwyczajny artefakt czy pozbawioną własnego znaczenia materię, której wszystkie właściwości muszą zostać umiejscowione w człowieku (61). O protezie nie sposób już mówić jak o czymś, do czego "intencjonalny podmiot może się odnieść, w co może się zaangażować lub do czego "przybliżyć«, przez procesy obiektywizacji czy ucieleśnienia" (207). Szczęka nie ulega tym samym w utworze ani funkcjonalnej, ani semantycznej eksploatacji, będąc raczej czynną przeszkodą w niczym dotąd niezakłóconej dominacji "ja". Każda próba jej noszenia daje poecie tytułową "szkołę", która zmusza go do uznania przedmiotu za równorzędną stronę „działania w świecie”.

Niedająca się spacyfikować proteza stawia teraz w stan podejrzenia nawet najbardziej dotychczas bezdyskusyjne humanistyczne nawyki. Oporne wobec hierarchizacji zęby zmuszają swego użytkownika do samokrytycznego dystansu, który przejawia się również w stosunku do wszystkich zakładających nadrzędność człowieka ontologii. Taka niemożność symbolicznego i funkcjonalnego opanowania szczęki staje się bowiem dla Białoszewskiego powodem nieustannego kwestionowania własnej sprawczości. Do wcześniejszego zwątpienia poety w tożsamościową esencjalność dołącza tu zatem poczucie utraty fundamentalnych dla tradycyjnego podmiotu prerogatyw - na czele z przełamywaniem oporu materii czy umiejętnością jej technicznej fabrykacji. Proteza przyczynia się w Szkole... do obnażenia pozorów ludzkiej omnipotencji, uprzywilejowanego statusu woli czy prymarnej roli intencjonalności. Za poetyckim rozpoznaniem "ja" jako nie-suwerennego bytu idzie natomiast konstatacja o końcu własnego monopolu na nadawanie struktury otaczającemu światu. Blisko stąd nie tylko do poststrukturalistycznego rozumienia podmiotu jako konstruowanego kulturowo projektu, w którym wytwarza się różnicę między człowiekiem a rzeczą, by móc sprawować nad nią niepodzielną władzę. Poprzez skupienie na niezapośredniczonej wyłącznie przez język rzeczywistości Białoszewski antycypuje zarazem postkonstruktywistyczną już z ducha świadomość sprawczości przedmiotów. Do tak rozumianego usytuowania protezy poeta odnosi się jednak z wyraźną rezerwą, z trudem przystając na nową dystrybucję kompetencji; na odsłonięcie nie-wystarczalności oraz nie-wyłączności własnego działania. Szczęka okazuje się dla niego kłopotliwym „innym”, którego, nie mogąc odrzucić, musi uznać teraz za odrębnego od siebie twórcę i sprawcę.

U Białoszewskiego żadna próba noszenia sztucznej szczęki nie może się zatem obyć bez wysiłku mediacji z jej niełatwą wielopoziomową „innością". Za wyrafinowanym "spektaklem ról społecznych", w którym maskuje się podmiotowe rozspojenie, kryją się ciągłe pertraktacje z działającymi "kontrproduktywnie” „trzecimi zębami”. Skuteczna „inkorporacja” protezy zależy tu jednak najbardziej od zrozumienia jej sprawczego statusu, od pojmowania sposobu istnienia rzeczy, co, jako jedyne, może zapewnić poecie wrażenie osobowej całości. Dalsze traktowanie "trzecich zębów” jako niemego przedmiotu skutkowałoby bowiem w utworze bezpowrotnym tożsamościowym samounieważnianiem, rozpatrywanym zarazem na poziomie tworzenia (niemożność mówienia i pisania), 
jak i społecznego funkcjonowania (towarzyski czy seksualny ostracyzm). Byłoby ono także poniechaniem uczestnictwa w świecie, który nie dawałby się już wówczas ani ująć w poetyckim dyskursie, ani nawet percepcyjnie doświadczyć. Pomyślana przez pryzmat sprawstwa sztuczna szczęka okazuje się tymczasem poręczycielką ludzkiej humanizacji, stabilizując lub destabilizując poczucie podmiotowej omnipotencji poety; zapośredniczając lub zakłócając jego odbiór rzeczywistości. Uznanie takiej roli protezy może doposażać teraz jej użytkownika w dyspozycję myślenia, mówienia, budowania związków z otoczeniem; odrzucenie podobnych sensów - ograniczać zaś jego uczestnictwo we wszystkich powyższych aktywnościach. Właściwe posługiwanie się "trzecimi zębami" oznacza tym samym gotowość na wejście z nimi w relację; a w poetyckiej praktyce - dopuszczenie do siebie myślenia o współ-konstytuowaniu (kształtowaniu, legitymizowaniu, wyrażaniu) ludzkiej tożsamości (por. Domańska 2007: 107). Nawet za cenę przemyślenia rekonfiguracji tradycyjnego statusu osoby, coraz mniej w takim układzie immanentnej, esencjalnej, jednostkowej.

Do noszenia protezy podchodzi się w Szkole... na wiele sposobów, odznaczających się nierównorzędną efektywnością i różnym poziomem dystansu do świata rzeczy. Ten repertuar ilustruje rozległą świadomościową przemianę, która przebiega na drodze eksperymentowania z konceptualizacją "trzecich zębów”. Ślady takiego procesu można odnaleźć choćby w relacji chóru głosów, które ilustrują zarówno postępującą bezradność tradycyjnego podmiotu, jak i poszukiwanie przez niego wyjścia z impasu. Udzielane Białoszewskiemu gremialnie rady dają się bowiem czytać nie tylko przez pryzmat dyscyplinującego społecznego rezonansu, ale i jako uzewnętrznienie osobistych rozterek poety (- przestanie boleć/ - przezwycięż/ - ty coś noś/ - czytaj w tym/ - gryź). Podobne wahanie wybrzmiewa zresztą najsilniej przy dostrzeżeniu sprawczości sztucznej szczęki, modyfikującej przebieg tworzenia tożsamościowego "ja" oraz podważającej fundamenty esencjalistycznych ontologii. Na wątpliwości towarzyszące takiemu myśleniu o rzeczach zwraca uwagę również humorystyczny już „powrót wypartego", kiedy konstytuująca tożsamość proteza zaczyna się objawiać jako stały motyw poetyckich marzeń sennych. Z jednej strony staje się to wyrazem demaskowania iluzoryczności podmiotowych prerogatyw - jedynie pozornej samoświadomości „ja”. Z drugiej, jest świadectwem niedającego o sobie zapomnieć działania rzeczy, wokół których nawet we śnie organizować się może poetycka wyobraźnia (W tych zębach sny/ z komplikacjami/ chce się coś wypluć/ nie można [...] jedyne wyjście/ przebudzenie/ o co chodziło?/ ach, tylko o jedne zęby i to te u mnie).

Stawką w grze o poczucie siebie jako "działającej w świecie” osoby okazuje się zatem świadomość nieustannych interakcji między człowiekiem a rzeczą. W utworze zdaje się to przekładać na uwzględnianie m a t e r i a I n e g o wpływu protezek na dyskursywne zmagania autora Szkoły... z zębową empirią. Narzekającego na uciążliwość noszenia protezy poetę można tu bowiem pojmować zarazem jako "przedmiot" sprawczości "trzecich zębów” i zdający sobie sprawę z własnej nie-autonomii podmiot, zaś jego iluzorycznie „scalaną” tożsamość - jako warunkowany przez rzeczy efekt „uspójniania" czy "uzupełniania”. Proteza przestaje być teraz jedynie "obiektem operacji wyobraźni” (Sandauer 1973: 378), zyskując w zamian znaczenie partycypanta w konstytuowaniu cielesnej, twórczej, wreszcie społecznej kondycji człowieka (zob. Domańska 2007: 113). Dzieląc uwagę na jedzenie, mówienie, przytrzymywanie w ustach zębowej konstrukcji, Białoszewski relacjonuje w utworze przebieg takiego fundującego osobę zbiorowego działania, kształtowanego na różnych etapach utworu raz bardziej przez ludzkie, raz bardziej przez nie-ludzkie byty. To, co osobowe jawi się dzięki temu jako pochodna intencjonalnych wysiłków poety, o których przebiegu, kierunku czy zakresie decydują 
również działające mu na przekór rzeczy. Pod pewnymi względami taka nie-posłuszna człowiekowi szczęka może nawet pełnić zadania „pierwszego poruszyciela”8 jego twórczych praktyk, odgrywać rolę aktywizatora wspólnotowej sprawczości (czego rezultatem jest choćby... uteatralnione noszenie "trzecich zębów" lub powstały na tej podstawie wiersz-partytura). Wobec rozproszenia pojęcia tożsamości czy działania wielowiekowy paradygmat humanitas ulega w utworze znacznemu przeorientowaniu. Coraz trudniej tu o stałe pozycje bytów (osoba/rzecz, podmiot/przedmiot) oraz związane z nimi arbitralne podziały (bierny/czynny, struktura/aktywność), coraz bliżej do mieszania się cech, zbiegania się funkcji i domen.

Taki obraz protezy z utworu mógłby już po części wyprzedzać namysł nad przekraczającą antropocentryczne nawyki ontologią. Byłby to namysł nad ludzkim „byciem w świecie”, które nie jest wyłącznie kognitywne lub kontemplatywne, ale opiera się zawsze na interaktywnym powiązaniu z rzeczami. Zdaniem Bjørnara Olsena, jednego z głównych rzeczników współczesnego „zwrotu ku rzeczom", to właśnie one zdradzają zdolność do oddziaływania na człowieka przez odnoszenie się do niego, warunkowanie jego myślenia, zapośredniczanie bliższych i dalszych relacji z otoczeniem (Gell 1998: 21-22). Pomimo braku intencjonalnej sprawczości, rzeczy nie muszą więc ewokować jedynie fizycznych związków przyczynowo-skutkowych (por. Olsen 2013: 209), co i tak niosłoby za sobą odzwierciedlenie właściwości ludzkiego podmiotu. Do uznania działania nie-będącego-człowiekiem bytu może już bowiem wystarczyć sam opór wobec woli użytkownika albo odmowa wpasowania się w porządek ludzkich oczekiwań (Domańska 2007: 113). Sprawczość staje się dzięki temu dyspozycją przechodnią i zawsze zależną od sytuacyjnego kontekstu. Uzewnętrznia to najmocniej teoria aktora-sieci Bruno Latoura, który w opisaniu powiązań ludzkich i nie-ludzkich bytów postuluje rezygnację z tradycyjnych humanistycznych klasyfikacji oraz pełną emancypację świata realiów. Radykalnie antyesencjalna ontologia filozofa dostrzega w rzeczach społecznych aktorów, powołujących w toku negocjacji z człowiekiem jego „splecioną” z wielu relacji tożsamość. Funkcjonuje ona w tej koncepcji na kształt sieci, co uniemożliwia ustanowienie podmiotowego "centrum", a nawet dominującego aktanta - głównego aktora działania. Dostrzeżenie sprawczości rzeczy idzie tu zatem w parze z oczekiwaną przez Latoura posthumanistyczną rewolucją, politycznym i etycznym demontażem systemu, który opiera się na dyskursie władzy i wiedzy.

Poetyckiemu wkraczaniu na teren "filozofii relacji" nie towarzyszy jednak wcale potrzeba dokonywania podobnie radykalnych przekroczeń. Analogicznie do wcześniejszych "gier w teatr" znoszenie humanistycznego systemu również tutaj ulega wyhamowaniu tuż przed realizacją wywrotowej przemiany. Z destabilizowania pozorów naturalności podmiotu Białoszewski czyni bowiem gest specyficznie osobny ${ }^{9}$, nie aspirujący żadną miarą do przeobrażeń szerszej społecznej rzeczywistości. Ten „wyciszony", kameralny demontaż odznacza się ponadto nie-emancypacyjnym charakterem motywacji, jakie kryją się za ujawnianiem sprawczego potencjału protezy. Z krytyczną diagnozą, stawianą przez poetę tradycyjnym tożsamościowym dyskursom, łączy się zatem w utworze najpierw nadzieja na powrót w domenę dawnych kompetencji, a następnie bolesna konieczność przystania na ich bezpowrotną utratę. Można by tu nawet zaryzykować twierdzenie, że najdalej idących prze-

8 Określenie to stosuję za Kowalczyk (2010), piszącą o przezwyciężaniu humanistycznego paradygmatu w relacjonistycznej ontologii Latoura.

${ }^{9}$ O typowych dla Białoszewskiego strategiach „osobnych” subwersji pisze szerzej Niżyńska (2008: 275). 
wartościowań Białoszewski dokonuje nie pod auspicjami polityczności, ale pod wpływem dramatycznie ubywającej mu egzystencji. Biorą się one szczególnie z poetyckiej potrzeby zminimalizowania lęku przed śmiercią, zintensyfikowanego gwałtownie wraz z ubytkiem własnych zębów.

"Stawanie się człowiekiem" dzięki rzeczom pozwala więc odczytać Szkołę... jako zapis projektu rekonstruowania tożsamości, obmyślanej na nowo w sytuacji utraty spójności ciała. Jest to relacja z powoływania hybrydalnego, współistniejącego z protezą człowieka, którego, choćby się chciało, nie sposób już dalej pojmować w izolacji. Pod wieloma względami utwór przypomina najbardziej partyturę naruszającego humanistyczne ramy poetyckiego performansu, w którym ludzkie splata się z nie-ludzkim, podobnie jak na latourowskiej społecznej scenie ${ }^{10}$. W toku pomniejszych teatralnych „działań" wytwarza się tutaj kolejno odczuwaną jako spójną tożsamość oraz iluzję osobowego scalenia, będące wyłącznie efektem zbiorowej sprawczości człowieka i zębowej protezy. Białoszewski zawdzięcza sztucznej szczęce współ-konstruowanie podmiotowego ideału, którego "produkcja” urzeczywistnia się zawsze "wobec" "trzecich zębów" - jako emocjonalna, konceptualna, twórcza odpowiedź na stawiany przez nie opór. Nie sposób jednak zapomnieć, że za każdym poetyckim współ-działaniem z protezą zawsze kryje się w Szkole... niezbywalna, fundamentalna dla humanitas potrzeba ucieczki przed śmiercią. Wszystkie czynione w utworze wysiłki re-integracji podmiotu ostatecznie mają bowiem na celu odroczenie wyroku jego reifikującego rozpadu. Są przeciwstawieniem się niekoordynowanemu już w żaden sposób demontażowi osoby i realizacji tanatycznej anihilacji.

U Białoszewskiego widać wyraźny rozziew między demaskowaniem niewystarczającego już do opisu rzeczywistości humanistycznego paradygmatu a arcyludzką, powodowaną egzystencjalnym lękiem, potrzebą jego podtrzymania. Z jednej więc strony poeta może się tu rozpoznać we wspólnocie z rzeczami, w postkonstruktywistycznym już, przynajmniej pod względem modusu, usytuowaniu; z drugiej zaś - jako "scalony" podmiot, nawet tymczasowy i bez "centrum"11 - może próbować powtórnego osadzenia się w obszarze "konstruktywistycznej” kultury. Tę sytuację zdaje się uwidaczniać zwłaszcza zakończenie utworu, kiedy poetyckie sięganie po humanistyczny kanon znajduje finał w przywołaniu motywu tańca śmierci (A kościotrupy /wszystkie na malowankach / maja świetne zęby / cie-ka-we / bo bez zębów co one?). Przez sposób opisywania uzębionych szkieletów Białoszewski paradoksalnie unieważnia jednak jakąkolwiek powagę recepcji "królewskiego tematu”. Jego wyposażeni w świetne zęby karykaturalni tańczący uobecniają tu bowiem obezwładniającą kulturową niemożność wytrwania przy nieprzetworzonej materii (por. Markowski 2002: 88). Uwidaczniają oni bezradność humanistycznych dyskursów, które odcięcie się od świata rzeczy rekompensują sobie ich coraz bardziej groteskowymi fantomami. Dla wyrażającego się w deziluzyjnym porządku poety taka perspektywa okazuje się w coraz większym stopniu nieadekwatna i nieaktu-

10 Jak pisze Kornat (2014), „Latour odwołuje się do metafory teatru, a byty nie-ludzkie zostają przez niego określone mianem aktorów. Nigdy nie wiadomo, kto jest podmiotem sprawczym i jak działa, podobnie jak w przypadku aktora, który nie gra sam na scenie. Jest on częścią działających w sieci podmiotów sprawczych/performatywnych".

11 Sytuacja radykalnie zmienia się bowiem w ostatnich, szpitalnych utworach poety ( $z$ tomu Oho i inne wiersze opublikowane po 1980 roku), gdzie schorowanemu poecie przychodzi współistnieć z protezą pęcherza. Piszę o tym więcej w rozdziale "Dosłowności biologiczne to potwory". Spotkania z (somatyczna) materia w pisarstwie Mirona Białoszewskiego (2013). 
alna. Jego żartobliwe „pokawałkowanie” (cie-ka-we) zdradza w zamian "złożone”, splecione z ludzkiego i nie-ludzkiego mówienie - wypadkową poetyckiego sylabizowania oraz samowolnego "kłapania" sztucznej szczęki.

\section{Bibliografia}

Bednarek, Joanna. 2012. Powrót „rzeczywistości”. W: (red.) Gajewska, Agnieszka. Teorie wywrotowe. Antologia przekładów. Poznań: Wydawnictwo Poznańskie, s. 227-240.

Białoszewski, Miron. 1994. „Odczepić się” i inne wiersze... Warszawa: PIW.

- - -. 2013. Donosy rzeczywistości. Warszawa: PIW.

Butler, Judith. 2010. Walczące słowa. Warszawa: Wydawnictwo Krytyki Politycznej.

Czapliński, Przemysław. 2012. Kamp - gry antropologiczne. W: „Teksty Drugie” nr 5, s. 11- 32.

Domańska, Ewa. 2007. Historie niekonwencjonalne. Refleksja o przeszłości w nowej humanistyce.

Poznań: Wydawnictwo Poznańskie.

- - -. 2008. Humanistyka (nie) antropocentryczna. W: „Kultura Współczesna” nr 3, s. 9-21.

Fellous, Michele. 2003. Przeszczep. Paradoks tożsamości i radykalnej obcości. W: „Kultura i Społeczeństwo" nr 3, s. 71-77.

Filipowicz, Anna. 2013. Sztuka mięsa. Somatyczne oblicza poezji. Gdańsk: Fundacja Terytoria Książki.

Gell, Alfred. 1998. Art and Agency. An Anthropological Theory. Oxford: Clarendon Press.

Gulik, Michał, Nowak, Samuel. 2013. Zapomnijcie o dyskursie. Czy możliwy jest latouriański feminizm? W: "Teksty Drugie" nr 5, s. 330-348.

Kanabrodzki, Mateusz. Kapłan i fryzjer. Wprowadzenie w żywioł materialno-cielesny w utworach Georga Buchnera, Witolda Gombrowicza, Mirona Białoszewskiego, Helmuta Kajzara. Gdańsk: słowo/ obraz terytoria.

Kopciński, Jacek. 1997. Gramatyka i mistyka. Wprowadzenie w teatralna osobność Mirona Biatoszewskiego. Warszawa: Wydawnictwo IBL PAN.

Kornat, Aleksandra. 2014. E. Domańska. Historia egzystencjalna. Krytyczne studium narratywizmu i humanistyki zaangażowanej (recenzja). W: "Studia z historii filozofii” nr 3, http://apcz.pl/czasopisma/index.php/szhf/article/view/szhf.2014.038; dostęp: 20.06.2015.

Kowalczyk, Agnieszka. 2010. Wspólnota poszerzona - spotkania ludzkich i pozaludzkich aktorów. W: „Praktyka Teoretyczna” nr 1, http://www.praktykateoretyczna.pl; dostęp: 20.06.2015.

Kristeva, Julia. 2007. Potęga obrzydzenia. Esej o wstręcie. Tłum. M. Falski. Kraków: Wydawnictwo Uniwersytetu Jagiellońskiego.

Markowski, Michał Paweł. 2002. Ciało (nowoczesne). W: „Res Publica Nowa” nr 9, s. 86-88.

Niżyńska, Joanna. 2008. „Znaleziony list" Mirona Białoszewskiego. Próba lektury "Małych narracji” w perspektywie teorii queer. W: (red.) Gosk, Hanna, Karwowska, Bożena. (Nie)obecność: pominięcia i przemilczenia w narracjach XX wieku. Warszawa: Wydawnictwo Uniwersytetu Warszawskiego, s. 272-291. 
Olsen, Bjornar. 2013. W obronie rzeczy. Archeologia i ontologia przedmiotów. Tłum. B. Shallcross. Warszawa: Wydawnictwo IBL PAN.

Rosiek, Stanisław. 1993. Pamiętnik z półgrobu. W: (red.) Głowiński, Michał, Łapiński, Zdzisław. Pisanie Białoszewskiego. Szkice. Warszawa: Wydawnictwo IBL PAN, s. 130-142.

- - -. 1997. Zwłoki Mickiewicza. Próba nekrografii poety. Gdańsk: słowo/ obraz terytoria.

Sandauer, Artur. 1973. Poeci trzech pokoleń. Warszawa: Ludowa Spółdzielnia Wydawnicza.

Sobolczyk, Piotr. 2002. "Wywiad" Mirona Białoszewskiego jako "wiersz ostatni”. W: „Ruch Literacki” nr 4-5, s. 475-484.

- - -. 2007. Hermetyczne pornografie Białoszewskiego. W: (red.) Bolecki, Włodzimierz, Nawrocka, Ewa. Literackie reprezentacje doświadczenia. Warszawa: Wydawnictwo IBL PAN, s. 326-328. 